\title{
Low-pay higher pay and job satisfaction within the European Union empirical evidence from fourteen countries
}

\author{
Luis Diaz-Serrano* \\ National University of Ireland Maynooth, \\ IZA and CREB \\ Jose A. Cabral Vieira* \\ University of the Azores \\ CEEAplA
}

\begin{abstract}
We examine differences in job satisfaction between low- and higher-paid workers within the European Union (EU). To do so The European Community Household Panel Data covering the period 1994-2001 is used. Then we test for differences in reported job satisfaction between low- and higher-paid workers. We also explain the existence of differences in the determinants of job satisfaction between these two types of workers and across countries. Our results indicate that low paid workers report a lower level of job satisfaction when compared with their higher paid counterparts in most countries, except in the UK. This supports the idea that low-wage employment in these countries mainly comprises low quality. The results also indicate that gap in average job satisfaction between low- and higher-paid workers is markedly wider in the Southern European countries than in the rest of EU. Finally, there are significant differences in the determinants of job satisfaction across countries. It seems then that a homogeneous policy may be inappropriate to increase satisfaction, and hence labour productivity, in the EU as a whole. Hence, an improvement of the quality of the jobs in the EU may require different policies. In particular, in some countries such as the United Kingdom removing low employment, namely through regulation, may worsen the workers' well-being, although in other cases such a policy may lead to a totally different outcome.
\end{abstract}

Running title: low-pay higher pay and job satisfaction

Key words: Job satisfaction, job quality, low-wage employment

JEL-Code: J28

\footnotetext{
* Department of Economics (Rhetoric House), National University of Ireland Maynooth, Co. Kildare, Ireland. E-mail: luis.diaz@nuim.ie.

- Department of Economics and Management. University of the Azores, Rua Mãe de Deus, 9500 Ponta

Delgada - Portugal. E-mail: josevieira@notes.uac.pt
} 


\section{Introduction}

Job satisfaction has become a matter of great interest in social sciences. It has been argued in the literature that answers to questions about how people feel toward their job are not meaningless but rather convey useful information on individual behavior such as job quits (Hamermesh, 1977, Freeman, 1978, McEvoy and Cascio,1985, Akerlof et al.,1988 and Shields and Price, 2002), absenteeism and productivity (Vroom, 1964, Mangione and Quinn, 1975, and Clegg, 1983). Moreover, job satisfaction is considered a strong predictor of overall individual well-being (Argyle, 1989 and Judge and Watanabe, 1993). As a consequence, several studies have attempted to identify the determinants of job satisfaction (see, Borjas, 1979, Miller, 1990, Meng, 1990, Idson, 1990, Clark, 1996 and 1997, Clark and Oswald, 1996 and Souza-Poza and Sousa-Poza, 2000).

In addition, the incidence and the persistence of low-pay employment has become a topic of concern in many developed economies as a result of increasing wage inequality (see OECD, 1996 and 1997, Asplund et al., 1998, Lucifora and Salverda, 1998, Stewart and Swaffield, 1999, Cappellari, 2000, Cardoso et al., 2000). Moreover, low pay employment and job quality have become important policy issues, namely in the European Union (see European Commission, 2001 and 2002). Also Salverda et al. (2001) put forward the idea that policies towards low-wage jobs should center on their quality at least as importantly as on the level of pay which they provide.

Job quality is a relative concept regarding objective characteristics of the jobworker match. It also involves the subjective evaluation of these characteristics by the respective worker, on the basis of his characteristics and expectations. The European Union Employment in Europe (2001) report suggests that in the absence of a single 
composite indicator any analysis of job quality must be based on data on both objective and subjective evaluations of the worker-job match. In addition, the European Union Employment (2002) report reinforces this stance with the suggestion of the inclusion of job satisfaction in its definition of job quality.

Indeed, Leontaridi and Sloane (2001) use job satisfaction as a proxy of job quality in the British labor market. Furthermore, they attempt to distinguish between two strands of the literature: the segmented labor market theory versus compensating wage differentials theories. The segmented labor market view, or, at least, the dual labor market version, claims the existence of two distinct labor markets with strong mobility barriers between them. In addition, this theory argues that we can classify jobs into good jobs and bad jobs, with bad jobs being those not only having worse working conditions, but also lower wages. As Leontaridi and Sloane (2001) argue, this contrasts with the compensating wage differentials theory according to which jobs with poor working conditions would be expected, ceteris paribus, to compensate for this with higher pay.

Leontaridi and Sloane (2001) surprisingly conclude that low pay workers report a higher job satisfaction than their higher pay counterparts. In their opinion, this casts doubt on the view that low paid jobs are bad jobs and that high paid jobs are good jobs. This is reinforced by their finding that it is by no means the case that moving from a low paid to a higher paid job increases job satisfaction. In sum, the results do not support the view that low paid jobs are inherently of low quality, at least as far as British evidence is concerned. This seems in line with a view that low paid workers likely obtain compensating differences in the form of non-pecuniary benefits. Jones and Sloane (2003) and Leontaridi et al. (2004) also present this type of conclusion. 
Apparently, there is a matching process in the labor market as a whole in which individuals seeking higher pay are allocated to higher-paying jobs and those seeking for non-pecuniary benefits are allocated to low-paying jobs. In such a case, removing low paid jobs, namely through regulation, would not necessarily improve worker's well being.

However, there is no reason to believe that such a type of findings hold for the other European labour markets. In this paper we also use job satisfaction as a proxy of job quality and attempt to shed further light on the issue, trough the examination of a large number of EU countries. For this purpose, we use seven waves of the European Community Household Panel (ECHP). The panel nature of the data allows us to use a random effects estimator in order to control for unobservable individual heterogeneity. The study takes advantage from the fact that period of analysis is the same for all countries. In addition, the data is based on a standardized questionnaire and the regressions use the same type of explanatory variables and estimation procedures. These features are suitable to perform comparisons among countries.

The paper is organized as follows. The next section describes the data and provides evidence on reported levels of job satisfaction by low and higher paid workers within fourteen EU countries. Section 3 evaluates the determinants of job satisfaction for low and high paid workers separately. Finally, section 4 concludes.

\section{The Data and variables}

The data used in this paper come from the European Community Household Panel (ECHP). This is a yearly panel of the EU-15 countries carried out by the Statistical Office of the European Communities (Eurostat) in cooperation with the National 
Statistical Office of each country. The data collection started in 1994 and was conducted over eight consecutive waves. We make use all waves of the ECHP, thus covering the 1994-2001 period, for ten of the EU-15 countries (Denmark, the Netherlands, Belgium, France, Ireland, Italy, Greece, Spain and Portugal). For Austria and Finland the available files only cover the period 1995-2001 and 1996-2001, respectively. During the period 1994-1996 the data for Germany and Luxembourg come from two different sources and the original ECHP files are mixed with the German Socioeconomic Panel (GSOEP) and the Luxembourg Household Panel (PSELL), respectively, whereas for the remaining waves covering the period 1997-2001 all the data come exclusively from the ECHP files. These ECHP files for Germany and Luxembourg do not provide valid answers about the question on job satisfaction, whereas the GSOEP and the PSELL do. Therefore, for these two countries we can only use the information covering the period 1994-1996. For the UK the data comes from two different sources, the ECHP for the period 1994-2001 and the British Household Panel Survey (BHPS) for the period 19942001. Both data sources provide valid answers on the question on job satisfaction. In this study we use both surveys. Finally, the Swedish ECHP files do not provide information on job satisfaction in any wave. Therefore, this country is omitted from our analysis.

The ECHP files contain information not only at household, but also very detailed data at individual level such as demographic information, employment status, job, education, training, earnings, hours worked, type of contract and a set of variables about the activity, size and sector of their employers. To our purposes the survey also provides answers on the level of satisfaction about some aspects of the individual's life. Of these questions, one refers to the individual's level of satisfaction with his/her job, 
where individuals are asked to report on a six-point scale how satisfied they were with their work or main activity. The lowest level of the scale stands for workers who were not satisfied at all whereas the highest stands for fully satisfied workers. To carry out our analysis we select males and females aged bellow 65 that are salary earners working in either the public or private sector. Thus, non-salary earners and self-employed dropped from the final sample.

As usual in most the literature, a low-wage worker is defined as an individual who earns less than two thirds of the median hourly wage. For this purpose, hourly wages were calculated as gross monthly wages divided by the number of hours worked per month. The corresponding values were transformed to 2001 prices through the consumer price index.

\section{Raw differences job satisfaction between low and higher paid workers}

Table 1 includes the sample mean values of job satisfaction broken by the lowpay threshold. There we also include the results concerning the test of the hypothesis of equality in the average job satisfaction between low-pay and higher pay workers. The results indicate that the mean level of job satisfaction is lower for low pay workers as compared with the one reported by their higher pay counterparts in most of the countries under analysis.

insert Table 1 about here

This supports the idea that low wage employment in these countries mainly comprises low quality jobs and is consistent with the segmented labor market theory, which claims the existence of good and bad jobs. The only clear exception to this 
pattern is the UK where low pay workers significantly report a higher level of satisfaction[1]. This is in consistent with the other results reported in previous studies for this country and in line with the notion that British low pay workers may obtain compensating differences in the form of non-pecuniary benefits (see Leontaridi and Sloane, 2001, and Leontaridi et al., 2004).

In addition, the difference in job satisfaction between low and higher pay workers is much more pronounced in Southern European countries such as Portugal, Spain, Greece and Italy. This may indicate that labor market segmentation and therefore differences in job quality, is less prominent in the other countries than in Southern of Europe.

\section{The determinants of job satisfaction}

\section{The Econometric model}

This section describes the econometric model to be used in order to assess the determinants of job satisfaction for low paid jobs and for higher paid jobs separately. As we have mentioned, the level of satisfaction is reported on a six-point ordinal scale. Therefore, a suitable estimator for our purposes is the ordered probit model. However, a common problem in ordinal scales is that surveyed individuals may have a different perception of the same scale. On the one hand, we might expect that individual's unobserved factors such as the emotional state or mood, which may vary across individuals, be also relevant for the outcome. On the other hand, we also might expect the observed and unobserved factors be correlated, which in turn may lead to inconsistent estimates. Given the panel nature of our data, one way for dealing with this problem would be the fixed-effects ordered probit model. Unfortunately, there is no 
available formulation yet to estimate such a model. Hence, one alternative option is the random-effects ordered probit model, which possesses the attractive feature that allows us to control for this individual's unobserved heterogeneity, although it does not allow for correlation between observed and unobserved determinants of satisfaction. This model is described below.

Assume that the propensity of individual $i$ to report a certain level of satisfaction in period $t$ is driven by the following structure:

$S_{i t}^{*}=\beta^{\prime} X_{i t}+v_{i t} \quad i=1, \ldots, N ; \quad t=1, \ldots, T$

where $S_{i t}^{*}$ is the latent outcome, $X_{i t}$ are the determinants of the outcome, $v_{i t}=\varepsilon_{i t}+u_{i}$ with $\operatorname{var}\left(v_{i t}\right)=\sigma_{\varepsilon}^{2}+\sigma_{u}^{2}=1+\sigma_{u}^{2}$ and $\rho_{v}=\frac{\sigma_{u}^{2}}{1+\sigma_{u}^{2}}$. The term $u_{i}$ picks up the individual's unobserved heterogeneity, which is assumed normally distributed with zero mean and variance $\sigma_{u}$, and $\varepsilon_{i t}$ is a time-varying error term distributed as $N(0,1)$.

Note that we do not observe $S_{i t}^{*}$ but observe instead an indicator variable of the type:

$S_{i t}=\left\{\begin{array}{lll}1 & \text { if } \quad S_{i t}^{*} \leq \mu_{0} \\ j & \text { if } \quad \mu_{j-1}<S_{i t}^{*} \leq \mu_{j}, \quad j=1,2,3,4 \\ 6 & \text { if } \quad S_{i t}^{*}>\mu_{4}\end{array}\right.$

The log-likelihood function reads:

$\log L=\sum_{i=1}^{N} \log P\left(S_{i 1}, \ldots, S_{i T}\right)$ 
Defining $a_{i t}=\mu_{j-1}-\beta^{\prime} X_{i t}$ and $b_{i t}=\mu_{j}-\beta^{\prime} X_{i t}$ we can write (3) as follows:

$$
\begin{aligned}
P\left(S_{i 1}, \ldots, S_{i T}\right)= & \int_{a_{i 1}}^{b_{i 1}} \ldots \int_{a_{i T}}^{b_{i T}} \phi\left(v_{i 1}, \ldots, v_{i T}\right) d v_{i 1} \ldots d v_{i T}= \\
& =\int_{a_{i 1}}^{b_{i 1}} \ldots \int_{a_{i T}}^{b_{i T}} \int_{-\infty}^{+\infty} \phi\left(\varepsilon_{i t} \mid u_{i}\right) \phi\left(u_{i}\right) d u_{i} d \varepsilon_{i T} \ldots d \varepsilon_{i 1}= \\
& =\int_{-\infty}^{+\infty} \phi\left(u_{i}\right) \prod_{t=1}^{T}\left[\Phi\left(b_{i t} \mid u_{i}\right)-\Phi\left(a_{i t} \mid u_{i}\right)\right] d u_{i}
\end{aligned}
$$

where $\phi$ and $\Phi$ denote the density function and the cumulative distribution function of the normal distribution, respectively. Therefore, the log-likelihood for this model can be generalized from the arguments made by Butler and Moffit (1982). Heterogeneity is handled by using the Gauss-Hermite quadrature to integrate out the joint density (see Frechette, 2001, for further details).

\section{Estimation results}

In order to identify the determinants of job satisfaction we relied on available evidence on the issue, which suggests that wages are important but do not explain the whole variation in reported levels of job satisfaction. For instance, Clark (1997) finds that after controlling for wages and for a large set of other covariates, females are happier at work than males. Moreover, it has been found that reported satisfaction depends on variables such the age of the worker, comparison wage rates, level of education, employer size, industry, union membership status, region, health status, type of employment contract, hours of work and educational mismatches, among others (see, for instance, Borjas, 1979, Miller, 1990, Meng, 1990, Idson, 1990, Clark, 1996 and 1997, Clark and Oswald, 1996, Leontaridi and Sloane, 2001, Sousa-Poza and SousaPoza, 2000 and Sloane and William, 2000 and Jones and Sloane, 2003). For the purpose 
of this work, we use as explanatory variables the logarithm of hourly wages, logarithm of hours worked, the individual's age and its squared, gender, education and marital and health status. Furthermore, we also control for employer size, use of foreign languages at work, skill mismatches, part-timers, type of contract (permanent or not), private versus public sector, employer size, occupations, regions, industries and whether the employer provides health care, training and subsidized housing. Estimations results are reported in Appendix.

One problem when interpreting the relationship between the outcome variable and the covariates in the ordered probit model is that the scaling of the coefficients is arbitrary. Hence, the comparison in the magnitude of the estimated effects across alternative models and samples requires the calculation of, for example, the average partial effects (APEs).

In the context of the random effects ordered probit model the APEs are functions of the covariates, $X_{i t}$, and the individual effect, $u_{i}$. These are based on $E\left[\Phi\left(X_{i t} \beta+u_{i}\right)\right]$, where the expectation is with respect to the distribution of $u_{\mathrm{i}}$. By replacing $u_{i}$ with $u_{i}=c_{0}+c_{i} \bar{X}_{i}+\alpha_{i}$, where $\bar{X}_{i}$ is the time-average of the covariates, and applying iterated expectations with respect $\bar{X}_{i}$ we get that the previous expectation now reads

$\Phi\left(X_{i t} \beta_{a}+c_{a 0}+c_{a i} \bar{X}_{i}\right)$,

where the subscript $a$ indicates the transformation of the original estimated parameters estimated by maximum likelihood into population averaged parameters, which in the random effects specifications are given by $\beta_{a}=\beta / \sqrt{1+\sigma_{u}^{2}}$. 
Wooldridge (2005) shows that a consistent estimator of the expected value of equation (5) with respect to the distribution of $\bar{X}_{i}$ is given by

$\frac{1}{N} \sum_{i=1}^{N} \Phi\left(X_{i t} \beta_{a}+c_{a 0}+c_{a i} \bar{X}_{i}\right)$

We can compute the APEs by evaluating changes in the derivatives of equation (6) with respect to $X_{\text {it. }}$ These values are also included in the tables Appendix.

As we can see, only a few results are similar across the board. For instance, a good health status influences job satisfaction positively (the only exceptions are for low paid workers in Portugal and Spain whose coefficients are not statistically different from zero). An evaluation of the APEs, however, indicates that this variable has a higher impact on satisfaction in countries such as Luxemburg, Austria and Germany, for low-paid workers, and in Ireland and the Netherlands for higher-paid workers. A worker's perceived over-qualification for the job generally reduces satisfaction. As in most of the literature, job satisfaction follows a U-shaped pattern with age. The evidence on the effect of most of the other variables is quite mixed across countries and between low and higher paid workers.

The effect of gender on job satisfaction differs significantly across countries and between the two types of workers under examination. For instance, females are happier at work than males in the United Kingdom which is in line with previous evidence for this country reported by Clark (1997). This is valid for low pay and higher pay workers. A similar finding holds for Luxemburg, Ireland and Spain. The impact of gender is however, higher within low-paid group in Luxemburg and Spain as compared with the higher-paid counterparts. On the other hand, this impact is higher within the higher paid group in UK and Ireland. As we can also observe, higher-paid females report a higher 
level of satisfaction with their job than males in countries such as Germany, Belgium and France, Italy and Greece but the difference coefficient is not statistically different from zero in the low pay group. In the Netherlands, males are happier with the job than females, but only in the higher pay segment (for low pay employees there no discernible gender effect). Finally, gender is not a distinguishing feature of job satisfaction for either group Portugal and Denmark.

Full-timers are less satisfied (with some clear exceptions such as for high paid workers in Portugal and Spain), although in most of the cases the coefficient is not significant for low pay workers. The evidence on the impact of working in the public sector is also very mixed. For instance, the distinction between public and private sectors does not affect satisfaction of either low- or higher-paid workers in Germany, Denmark, The Netherlands and Finland. However, working in the public sector affects positively the satisfaction of higher paid workers in Belgium, Luxemburg, Ireland, Portugal and Austria, but has no significant effect on the satisfaction of low-paid workers. It exerts a positive effect on the satisfaction of both types of workers in countries such as France, Italy, Greece and Spain. In the UK, higher paid workers in public services are less satisfied with the job than those in the private sector, but the opposite occurs in the low-pay segment.

Hourly wages is a determinant of job satisfaction for higher paid workers in most of the countries. The evidence is, however, quite mixed with respect to low-paid workers. With respect to benefits provided by the employer, it is worth mentioning that the provision of training has a positive impact on satisfaction for both types of workers in Germany, Denmark, The Netherlands, Belgium, United Kingdom, Spain and Finland (likely because training has a promotion prospect even for low-paid workers). It has 
however no visible effect on the job satisfaction of low paid workers in Luxemburg, France, Italy, Greece, Portugal and Austria. Other significant differences across countries and between the two segments were found for the impact of hours of work per week, education, previous unemployment, benefits provided by the employer, the use of languages at work, type of contract, firm size, occupations and industries.

\section{Conclusions and remarks}

In this paper we have examined differences in job satisfaction between low- and higher-paid workers within the European Union (EU). The results indicate that low pay workers report a lower level of job satisfaction when compared with their higher paid counterparts in most of the countries. This is consistent with the existence of good and bad jobs, as in dual labor markets, where some workers are involuntarily trapped in bad jobs (i.e. low-wage) segment. This also supports the European Commission concern that low pay jobs are inherently of low quality

The only clear exception to the aforementioned pattern is the United Kingdom, where low pay workers report a higher level of satisfaction, which is in consistent with the results reported in previous studies for this country and in line with the notion that British low pay workers may obtain compensating differences in the form of nonpecuniary benefits. Moreover, the difference in job satisfaction between low and higher pay workers is much more pronounced in Southern countries such as Portugal, Spain, Greece and Italy. This may indicate that labor market segmentation and therefore differences in job quality are more profound in these countries.

In addition, some of the determinants of job satisfaction widely used in the literature such as gender, hours of work, among others, differ significantly between the 
two segments in most of the countries. Finally, we find important differences in the determinants of job satisfaction across countries. The results also suggest that empirical evidence on job quality can hardly be generalized across the European labor markets. This is particularly important for policy making at the European Union level. Such a heterogeneity means that in some countries such as the United Kingdom removing low employment, namely through regulation, may worsen the workers' well-being, although in other cases such a policy may lead to a totally different outcome.

\section{Notes}

1. Although the average level of satisfaction is also higher for low pay workers in Denmark, the difference between the two groups of workers is not statistically significant.

2. Such as mentioned above one limitation of the random effects ordered probit model is that it does not allow for correlation between the individual specific effect $\left(u_{i}\right)$ and the explanatory variables $\left(X_{i t}\right)$. To some extent this no-correlation assumption is at least questionable. Because of this, we have also estimated a pooled ordered probit model with a clustering correction by individuals. This clustering allows us to relax the no-correlation assumption. Second, we estimate a fixed-effects linear regression model that allows for dependence between the individual's unobserved heterogeneity and the covariates. Although the estimated parameters coming from these estimators (not reported) are not directly comparable with the ones obtained with the random-effects ordered probit model, the fact that the significance and sign of the estimated coefficients in each country persist across these three alternative may increases the robustness of our results. 


\section{References}

Akerlof, G., Rose, A. and Yellen, J. (1988), “Job switching and job satisfaction in the US labor market”, Brookings Papers on Economic Activity, Vol. 0 No.2, pp. 495582.

Argyle, M. (1989), The Psychology of Happiness, Routledge, London.

Asplund, R., Sloane, P. and Theodossiou, I. (1998), Low Pay and Earnings Mobility in Europe, Edward Elgar, Cheltenham.

Borjas, G. (1979) “Job satisfaction, wages and unions”, Journal of Human Resources, Vol. 14 No.1, pp. 21-40.

Butler, J. and Moffit, R. (1982), “A computational efficient quadrature procedure for the one factor multinomial probit model”, Econometrica, Vol. 50 No.3, pp. 761-764.

Cappellari, L. (2000), “Low-wage mobility in the Italian labour market”, International Journal of Manpower, Vol. 21 No.: 264-290.

Cardoso, A., Sousa, R., Castro, V. and Ferreira, P. (2000), “O perfil do trabalhador e da empresa de baixos salários em Portugal”, Economia, Vol. 24, pp. 53-66.

Clark, A. (1997), “Job satisfaction and gender: why are women so happy at work?”, Labour Economics, Vol. 4 No. 4, pp. 341-372.

Clark, A. (1996), “Job satisfaction in Britain”, British Journal of Industrial Relations, Vol. 34 No. 2, pp. 189-217.

Clark, A. and Oswald, A. (1996), "Satisfaction and comparison income”, Journal of Public Economics, Vol. 61 No.3, pp. 359-381.

Clegg, C. (1983), “Psychology of employee lateness, absence and turnover: methodological, as critique and empirical study”, Journal of Applied Psychology, Vol. 68, pp. 88-101. 
European Commission (2001), Employment in Europe 2001: Recent Trends and Prospects, in Employment and Social Affairs, Chapter 4, Luxembourg.

European Commission (2002) Employment in Europe 2002: Recent Trends and Prospects, in Employment and Social Affairs, Chapter 3, Luxembourg.

Frechette, G. (2001), “Random-effects ordered probit”, Stata Technical Bulletin, Vol. 59, January, pp. 23-27.

Freeman, R. (1978) “Job satisfaction as an economic variable”, American Economic Review Papers and Proceedings, Vol. 68 No.2, pp. 135-141.

Hamermesh, D. (1977), “Economic aspects of job satisfaction”, in Ashenfelter, O. and Oates, W. (Ed.), Essays in Labor Market Analysis, John Wiley, New York, pp. 5372.

Idson, T. (1990), “Establishment size, job satisfaction and the structure of work”, Applied Economics, Vol. 22 No.8, pp. 1007-19.

Jones, R. and Sloane, P. (2003), "Low pay higher pay and job satisfaction in Wales", WELMERC Discussion paper Nº. 2003-03, University of Wales Swansea.

Judge, T. and Watanabe, S. (1993), “Another look at the job satisfaction - life satisfaction relationship”, Journal of Applied Psychology, Vol. 78 No. 6, pp. 93948.

Leontaridi, R. and Sloane, P. (2001), "Measuring the Quality of Jobs: Promotion Prospects, Low Pay and Job Satisfaction”, LoWER Working Paper Nº. 07, University of Amsterdam. Leontaridi, R., Sloane, P. and Jones, R. (2004), “Are Low Paid Jobs of Low Quality? Some British Evidence”, WELMERC Discussion paper Nº. 2004-02, University of Wales Swansea. 
Lucifora, C. and Salverda, W. (1998), Policies for Low Wage Employment and Social Exclusion in Europe, FrancoAngeli, Milan.

Magione, T. and Quinn, R. (1975), “Job satisfaction, counterproductive behaviour and drog used at work”, Journal of Applied Psychology, Vol. 60, pp. 114-16.

McEvoy, G. and Cascio, W. (1985), “Strategies for reducing employee turnover: a meta analysis”, Journal of Applied Psychology, Vol. 70 No.2, pp. 342-53.

Meng, R. (1990), “The relationship between trade unions and job satisfaction”, Applied Economics, Vol. 22 No.12, pp. 1635-48.

Miller, P. (1990), “Trade unions and job satisfaction”, Australian Economic Papers, Vol. 29 No.55, pp. 226-48.

OECD (1997), “Earnings mobility: taking a longer run view”, in Employment Outlook 1997, pp. 27-61, Paris.

OECD (1996), “Earnings inequality, low-paid employment and earnings mobility”, in Employment Outlook 1996, pp. 59-108, Paris.

Salverda, W., Bazen, S. and Gregory, M. (2001), The European-American employment gap, wage inequality, earnings mobility and skill: a study for France; Germany, the Netherlands, the United Kingdom and the United States, European Low-wage Employment Research Network (LOWER), Final Report, University of Amsterdam. Shields, M. and Price, S. (2002), “Racial harassment, job satisfaction and intentions to quit: evidence from the Bristish nursing profession”, Economica, Vol. 69 No.274, pp. 295-362.

Sloane, P. and William, H. (2000), “Job satisfaction, comparison earnings and gender”, Labour, Vol. 14 No.3, pp. 473-501. 
Sousa-Poza, A. and Sousa-Poza, A. (2000), “Taking another look at the gender/job satisfaction paradox”, Kyklos, Vol.53 No.2, pp. 135-52.

Stewart, M. and Swaffield, J. (1999), "Low pay dynamics and transition probabilities”, Economica, Vol.66 No.261, pp. 23-42.

Vroom, V. (1964), Work and Motivation, Wiley, New York.

Wooldridge, J.M. (2005), "Simple solutions to the initial conditions problem in dynamic, nonlinear panel data models with unobserved hetegeneity”, Journal of Applied Econometrics, Vol.20 No.1, pp. 39-54. 
Table 1 - Sample statistics and test for the equality of means on reported low satisfaction between low-pay and higher-pay workers

\begin{tabular}{|c|c|c|c|c|c|c|c|c|}
\hline \multirow[b]{3}{*}{ Germany } & \multicolumn{3}{|c|}{ Sample size } & \multirow{2}{*}{$\begin{array}{l}\text { Mean } \\
\text { er-pay }\end{array}$} & \multirow{2}{*}{\multicolumn{2}{|c|}{$\frac{\text { Standard deviation }}{\text { Low-pay Higher-pay }}$}} & \multirow{3}{*}{$\begin{array}{r}\text { Mean } \\
\text { Difference }\end{array}$} & \multirow{3}{*}{$\begin{array}{r}\text { t-statistic } \\
10.39\end{array}$} \\
\hline & \multicolumn{2}{|c|}{ Low-pay Higher-pay } & \multirow{2}{*}{$\begin{array}{r}\text { Low-pay } \\
4.15\end{array}$} & & & & & \\
\hline & 1,944 & 10,840 & & 4.42 & 1.22 & 1.05 & & \\
\hline Denmark & 1,486 & 18,424 & 4.96 & 4.94 & 1.09 & 0.97 & -0.02 & -0.60 \\
\hline The Netherlands & 3,580 & 30,632 & 4.73 & 4.75 & 0.98 & 0.87 & 0.02 & 1.11 \\
\hline Belgium & 1,341 & 17,741 & 4.30 & 4.47 & 1.34 & 1.15 & 0.17 & 5.24 \\
\hline Luxembourg & 537 & 2,177 & 4.43 & 4.84 & 1.26 & 1.01 & 0.41 & 8.05 \\
\hline France & 6,026 & 35,073 & 4.25 & 4.45 & 1.19 & 1.02 & 0.20 & 13.97 \\
\hline UK & 6,444 & 36,145 & 4.41 & 4.32 & 1.33 & 1.23 & -0.08 & -4.96 \\
\hline Ireland & 3,010 & 13,715 & 4.38 & 4.65 & 1.33 & 1.15 & 0.26 & 11.04 \\
\hline Italy & 3,813 & 37,039 & 3.31 & 4.11 & 1.44 & 1.24 & 0.81 & 37.65 \\
\hline Greece & 3,134 & 17,243 & 3.13 & 4.02 & 1.21 & 1.18 & 0.89 & 38.91 \\
\hline Spain & 5,919 & 29,048 & 3.83 & 4.35 & 1.41 & 1.21 & 0.52 & 29.16 \\
\hline Portugal & 4,232 & 30,508 & 3.68 & 4.07 & 1.04 & 0.89 & 0.40 & 26.71 \\
\hline Austria & 1,922 & 17,459 & 4.75 & 4.97 & 1.19 & 0.96 & 0.22 & 9.16 \\
\hline Finland & 1,492 & 16,334 & 4.49 & 4.59 & 1.11 & 0.96 & 0.10 & 3.79 \\
\hline
\end{tabular}


Annex

Random effects ordered probit estimates

\begin{tabular}{|c|c|c|c|c|c|c|c|c|c|c|c|c|}
\hline & \multicolumn{6}{|c|}{ Germany } & & & & \multicolumn{3}{|c|}{ Denmark } \\
\hline & \multicolumn{3}{|c|}{ Low-wage } & \multicolumn{3}{|c|}{ Higher-wage } & \multicolumn{3}{|c|}{ Low-wage } & \multicolumn{3}{|c|}{ Higher-wage } \\
\hline & Coeff. & APE & z-value & Coeff. & APE & z-value & Coeff. & APE & z-value & Coeff. & APE & z-value \\
\hline log(hourly wage) & 0.021 & 0.006 & 0.22 & 0.393 & 0.083 & 6.63 & -0.133 & -0.039 & -1.67 & 0.263 & 0.041 & 4.14 \\
\hline log(weekly hours) & -0.061 & -0.017 & -0.38 & 0.277 & 0.059 & 2.67 & -0.038 & -0.011 & -0.32 & 0.363 & 0.057 & 4.40 \\
\hline Age & -0.015 & -0.004 & -0.70 & -0.061 & -0.013 & -4.99 & -0.038 & -0.011 & -1.77 & -0.032 & -0.005 & -3.31 \\
\hline Age Squared/100 & 0.019 & 0.006 & 0.69 & 0.085 & 0.018 & 5.73 & 0.066 & 0.019 & 2.34 & 0.051 & 0.008 & 4.40 \\
\hline Gender (Male) & -0.097 & -0.028 & -1.05 & -0.215 & -0.045 & -4.57 & 0.090 & 0.026 & 1.06 & 0.008 & 0.001 & 0.22 \\
\hline Secondary Education & 0.021 & 0.006 & 0.18 & 0.085 & 0.018 & 1.81 & -0.043 & -0.013 & -0.39 & 0.006 & 0.001 & 0.20 \\
\hline Primary or lower Education & 0.111 & 0.032 & 0.83 & 0.091 & 0.019 & 1.57 & 0.150 & 0.044 & 1.23 & 0.012 & 0.002 & 0.28 \\
\hline Good Health Status & 0.423 & 0.122 & 5.34 & 0.427 & 0.090 & 12.19 & 0.291 & 0.086 & 2.89 & 0.364 & 0.057 & 11.04 \\
\hline $\begin{array}{l}\text { Previously unemployed } \\
\text { Job characteristics }\end{array}$ & -0.167 & -0.048 & -2.10 & -0.148 & -0.031 & -3.01 & 0.064 & 0.019 & 0.77 & -0.023 & -0.004 & -0.64 \\
\hline Overskilled & -0.256 & -0.073 & -3.48 & -0.251 & -0.053 & -7.19 & -0.300 & -0.088 & -3.78 & -0.216 & -0.034 & -7.97 \\
\hline Use of languages & 0.390 & 0.112 & 3.29 & -0.038 & -0.008 & -0.89 & 0.070 & 0.021 & 0.78 & -0.057 & -0.009 & -1.97 \\
\hline Traning at the moment & 0.129 & 0.037 & 1.67 & 0.036 & 0.008 & 1.17 & 0.045 & 0.013 & 0.58 & 0.042 & 0.007 & 1.93 \\
\hline Permanent contract & 0.183 & 0.052 & 1.99 & 0.121 & 0.026 & 2.25 & 0.200 & 0.059 & 2.37 & -0.006 & -0.001 & -0.16 \\
\hline Full-time & -0.142 & -0.041 & -1.06 & -0.129 & -0.027 & -1.60 & -0.077 & -0.023 & -0.68 & -0.153 & -0.024 & -2.73 \\
\hline Public worker & -0.018 & -0.005 & -0.18 & 0.037 & 0.008 & 0.75 & 0.134 & 0.039 & 1.47 & 0.019 & 0.003 & 0.57 \\
\hline$\mu_{1}$ & -2.700 & & -4.03 & -1.923 & & -4.43 & -3.355 & & -6.57 & -1.651 & & -4.55 \\
\hline$\mu_{2}$ & -1.971 & & -2.96 & -1.185 & & -2.74 & -2.724 & & -5.45 & -1.057 & & -2.92 \\
\hline$\mu_{3}$ & -1.007 & & -1.52 & -0.140 & & -0.32 & -2.116 & & -4.29 & -0.381 & & -1.05 \\
\hline$\mu_{4}$ & 0.000 & & 0.00 & 0.956 & & 2.21 & -1.263 & & -2.58 & 0.642 & & 1.77 \\
\hline$\mu_{5}$ & 1.552 & & 2.35 & 2.738 & & 6.32 & -0.068 & & -0.14 & 2.183 & & 6.03 \\
\hline$\rho$ & 0.414 & & 11.75 & 0.412 & & 32.29 & 0.291 & & 5.94 & 0.409 & & 41.02 \\
\hline Log-likelihood & & $-2,858$ & & & $-13,789$ & & & $-1,919$ & & & $-21,558$ & \\
\hline LR Chi-test & & 159 & & & 596 & & & 112 & & & 612 & \\
\hline \# of observations & & 1,944 & & & 10,484 & & & 1,486 & & & 18,218 & \\
\hline
\end{tabular}

Note: Estimates also include dummy controls for employer facilities (insurance, housing, training and leisure), employer size, occupations, industry, region and year. 
Random effects ordered probit estimates

\begin{tabular}{|c|c|c|c|c|c|c|c|c|c|c|c|c|}
\hline & \multicolumn{6}{|c|}{ The Netherlands } & \multicolumn{6}{|c|}{ Belgium } \\
\hline & \multicolumn{3}{|c|}{ Low-wage } & \multicolumn{3}{|c|}{ Higher-wage } & \multicolumn{3}{|c|}{ Low-wage } & \multicolumn{3}{|c|}{ Higher-wage } \\
\hline & Coeff. & APE & z-value & Coeff. & APE & z-value & Coeff. & APE & z-value & Coeff. & APE & z-value \\
\hline log(hourly wage) & 0.059 & 0.014 & 1.63 & 0.143 & 0.043 & 5.15 & 0.145 & 0.035 & 1.29 & 0.357 & 0.046 & 6.92 \\
\hline log(weekly hours) & -0.063 & -0.015 & -0.71 & 0.035 & 0.010 & 0.70 & 0.580 & 0.140 & 3.76 & 0.539 & 0.070 & 7.48 \\
\hline Age & -0.065 & -0.016 & -4.60 & -0.062 & -0.018 & -8.43 & -0.112 & -0.027 & -3.88 & -0.070 & -0.009 & -6.83 \\
\hline Age Squared/100 & 0.088 & 0.021 & 4.52 & 0.077 & 0.023 & 8.57 & 0.151 & 0.037 & 3.99 & 0.090 & 0.012 & 7.05 \\
\hline Gender (Male) & -0.026 & -0.006 & -0.49 & 0.071 & 0.021 & 3.52 & -0.067 & -0.016 & -0.71 & -0.145 & -0.019 & -5.40 \\
\hline Secondary Education & 0.099 & 0.024 & 1.04 & 0.053 & 0.016 & 2.12 & 0.174 & 0.042 & 1.68 & -0.003 & 0.000 & -0.08 \\
\hline Primary or lower Education & 0.043 & 0.010 & 0.46 & 0.042 & 0.013 & 1.53 & 0.210 & 0.051 & 1.81 & 0.072 & 0.009 & 1.92 \\
\hline Good Health Status & 0.311 & 0.074 & 5.32 & 0.347 & 0.104 & 17.24 & 0.322 & 0.078 & 3.26 & 0.404 & 0.052 & 14.59 \\
\hline \multicolumn{13}{|l|}{ Job characteristics } \\
\hline$\overline{\text { Overskilled }}$ & -0.157 & -0.038 & -3.62 & -0.103 & -0.031 & -6.72 & -0.427 & -0.103 & -5.14 & -0.203 & -0.026 & -8.99 \\
\hline Use of languages & -0.032 & -0.008 & -0.58 & 0.001 & 0.000 & 0.04 & -0.076 & -0.018 & -0.76 & 0.028 & 0.004 & 1.06 \\
\hline Traning at the moment & -0.090 & -0.022 & -1.58 & -0.053 & -0.016 & -2.33 & 0.042 & 0.010 & 0.45 & 0.009 & 0.001 & 0.39 \\
\hline Permanent contract & 0.145 & 0.035 & 3.01 & 0.007 & 0.002 & 0.25 & 0.050 & 0.012 & 0.52 & -0.011 & -0.001 & -0.33 \\
\hline Full-time & -0.029 & -0.007 & -0.42 & -0.124 & -0.037 & -3.61 & -0.404 & -0.097 & -2.92 & -0.256 & -0.033 & -5.06 \\
\hline Public worker & -0.014 & -0.003 & -0.22 & 0.022 & 0.006 & 1.11 & 0.050 & 0.012 & 0.48 & 0.108 & 0.014 & 3.90 \\
\hline$\mu_{1}$ & -3.917 & & -10.78 & -3.632 & & -16.33 & -1.436 & & -1.90 & -0.874 & & -2.60 \\
\hline$\mu_{2}$ & -3.242 & & -9.12 & -3.026 & & -13.71 & -0.881 & & -1.17 & -0.300 & & -0.89 \\
\hline$\mu_{3}$ & -2.511 & & -7.13 & -2.284 & & -10.38 & -0.007 & & -0.01 & 0.496 & & 1.48 \\
\hline$\mu_{4}$ & -1.493 & & -4.26 & -1.133 & & -5.15 & 0.810 & & 1.08 & 1.493 & & 4.45 \\
\hline$\mu_{5}$ & 0.008 & & 0.02 & 0.597 & & 2.72 & 2.028 & & 2.71 & 2.944 & & 8.76 \\
\hline$\rho$ & 0.258 & & 10.58 & 0.286 & & 36.11 & 0.383 & & 9.59 & 0.370 & & 36.36 \\
\hline Log-likelihood & \multicolumn{3}{|c|}{$-4,580$} & \multicolumn{3}{|c|}{$-35,238$} & \multicolumn{3}{|c|}{$-2,022$} & \multicolumn{3}{|c|}{$-23,516$} \\
\hline LR Chi-test & \multicolumn{3}{|c|}{120} & \multicolumn{3}{|c|}{695} & \multirow{2}{*}{\multicolumn{3}{|c|}{142}} & \multicolumn{3}{|c|}{802} \\
\hline \# of observations & \multicolumn{3}{|c|}{3,580} & \multicolumn{3}{|c|}{30,627} & & & & \multicolumn{3}{|c|}{17,425} \\
\hline
\end{tabular}

Note: Estimates also include dummy controls for employer facilities (insurance, housing, training and leisure), employer size, occupations, industry, region and year. 
Random effects ordered probit estimates

\begin{tabular}{|c|c|c|c|c|c|c|c|c|c|c|c|c|}
\hline & \multicolumn{6}{|c|}{ Luxembourg } & \multicolumn{6}{|c|}{ France } \\
\hline & \multicolumn{3}{|c|}{ Low-wage } & \multicolumn{3}{|c|}{ Higher-wage } & \multicolumn{3}{|c|}{ Low-wage } & \multicolumn{3}{|c|}{ Higher-wage } \\
\hline & Coeff. & APE & z-value & Coeff. & APE & z-value & Coeff. & APE & z-value & Coeff. & APE & z-value \\
\hline log(hourly wage) & -0.198 & -0.053 & -0.73 & 0.651 & 0.149 & 4.09 & -0.146 & -0.047 & -3.25 & 0.414 & 0.027 & 14.05 \\
\hline log(weekly hours) & 0.627 & 0.168 & 1.54 & 0.116 & 0.026 & 0.33 & 0.010 & 0.003 & 0.13 & 0.490 & 0.033 & 10.01 \\
\hline Age & -0.052 & -0.014 & -1.01 & -0.087 & -0.020 & -2.44 & -0.017 & -0.005 & -1.36 & -0.033 & -0.002 & -4.28 \\
\hline Age Squared/100 & 0.062 & 0.017 & 0.90 & 0.107 & 0.025 & 2.41 & 0.018 & 0.006 & 1.10 & 0.035 & 0.002 & 3.62 \\
\hline Gender (Male) & -0.599 & -0.160 & -2.99 & -0.292 & -0.067 & -2.53 & -0.049 & -0.016 & -1.14 & -0.091 & -0.006 & -4.05 \\
\hline Secondary Education & -0.534 & -0.143 & -1.40 & -0.144 & -0.033 & -1.14 & 0.027 & 0.009 & 0.51 & 0.002 & 0.000 & 0.07 \\
\hline Primary or lower Education & -0.407 & -0.109 & -1.10 & 0.072 & 0.016 & 0.52 & 0.058 & 0.019 & 1.07 & 0.082 & 0.005 & 2.77 \\
\hline Good Health Status & 0.373 & 0.100 & 2.50 & 0.272 & 0.062 & 3.09 & 0.446 & 0.143 & 12.36 & 0.439 & 0.029 & 26.37 \\
\hline Previously unemployed & -0.447 & -0.120 & -1.93 & -0.361 & -0.082 & -1.85 & -0.107 & -0.034 & -2.43 & -0.050 & -0.003 & -1.59 \\
\hline \multicolumn{13}{|l|}{ Job characteristics } \\
\hline Overskilled & -0.617 & -0.165 & -3.83 & -0.301 & -0.069 & -3.46 & -0.275 & -0.088 & -8.09 & -0.181 & -0.012 & -11.28 \\
\hline Use of languages & 0.171 & 0.046 & 0.76 & -0.045 & -0.010 & -0.28 & 0.133 & 0.043 & 2.25 & 0.047 & 0.003 & 2.07 \\
\hline Traning at the moment & -0.053 & -0.014 & -0.26 & 0.031 & 0.007 & 0.38 & 0.190 & 0.061 & 3.99 & 0.062 & 0.004 & 2.94 \\
\hline Permanent contract & -0.212 & -0.057 & -0.96 & 0.031 & 0.007 & 0.16 & 0.020 & 0.006 & 0.46 & 0.076 & 0.005 & 2.29 \\
\hline Full-time & -0.380 & -0.102 & -1.20 & -0.012 & -0.003 & -0.05 & 0.060 & 0.019 & 0.92 & -0.148 & -0.010 & -3.83 \\
\hline Public worker & 0.288 & 0.077 & 0.94 & 0.370 & 0.084 & 2.83 & 0.139 & 0.045 & 2.72 & 0.240 & 0.016 & 9.81 \\
\hline$\mu_{1}$ & -2.286 & & -1.38 & -2.629 & & -1.96 & -2.019 & & -5.81 & -0.442 & & -1.95 \\
\hline$\mu_{2}$ & -1.791 & & -1.08 & -1.955 & & -1.46 & -1.584 & & -4.56 & 0.067 & & 0.30 \\
\hline$\mu_{3}$ & -1.079 & & -0.65 & -1.205 & & -0.90 & -0.919 & & -2.65 & 0.818 & & 3.61 \\
\hline$\mu_{4}$ & -0.103 & & -0.06 & -0.046 & & -0.03 & 0.082 & & 0.24 & 2.067 & & 9.12 \\
\hline$\mu_{5}$ & 1.701 & & 1.04 & 1.772 & & 1.32 & 1.740 & & 5.01 & 4.025 & & 17.71 \\
\hline$\rho$ & 0.458 & & 7.42 & 0.503 & & 18.69 & 0.280 & & 14.91 & 0.364 & & 48.06 \\
\hline Log-likelihood & \multicolumn{3}{|c|}{-730} & \multicolumn{3}{|c|}{$-2,601$} & \multicolumn{3}{|c|}{$-8,424$} & \multicolumn{3}{|c|}{$-37,928$} \\
\hline LR Chi-test & \multicolumn{3}{|c|}{76} & \multicolumn{3}{|c|}{156} & \multicolumn{3}{|c|}{481} & \multicolumn{3}{|c|}{1807} \\
\hline \# of observations & \multicolumn{3}{|c|}{537} & \multicolumn{3}{|c|}{2172} & \multicolumn{3}{|c|}{6.026} & \multicolumn{3}{|c|}{31.750} \\
\hline
\end{tabular}

Note: Estimates also include dummy controls for employer facilities (insurance, housing, training and leisure), employer size, occupations, industry, region and year. 
Random effects ordered probit estimates

\begin{tabular}{|c|c|c|c|c|c|c|c|c|c|c|c|c|}
\hline & \multicolumn{6}{|r|}{$\overline{\mathrm{UK}}$} & & & & \multicolumn{3}{|c|}{ Ireland } \\
\hline & \multicolumn{3}{|c|}{ Low-wage } & \multicolumn{3}{|c|}{ Higher-wage } & \multicolumn{3}{|c|}{ Low-wage } & \multicolumn{3}{|c|}{ Higher-wage } \\
\hline & Coeff. & APE & z-value & Coeff. & APE & z-value & Coeff. & APE & $\overline{\text { z-value }}$ & Coeff. & APE & z-value \\
\hline $\log$ (hourly wage) & -0.109 & -0.011 & -1.83 & 0.239 & 0.063 & 8.32 & 0.272 & 0.052 & 2.78 & 0.261 & 0.076 & 5.34 \\
\hline log(weekly hours) & -0.052 & -0.005 & -0.70 & -0.093 & -0.025 & -2.17 & 0.347 & 0.066 & 2.99 & 0.030 & 0.009 & 0.40 \\
\hline Age & -0.047 & -0.005 & -4.30 & -0.039 & -0.010 & -6.44 & -0.032 & -0.006 & -1.87 & -0.042 & -0.012 & -4.52 \\
\hline Age Squared/100 & 0.070 & 0.007 & 4.79 & 0.056 & 0.015 & 7.32 & 0.048 & 0.009 & 2.06 & 0.062 & 0.018 & 5.27 \\
\hline Gender (Male) & -0.251 & -0.026 & -4.83 & -0.281 & -0.074 & -12.18 & -0.153 & -0.029 & -2.20 & -0.184 & -0.053 & -4.79 \\
\hline Secondary Education & 0.009 & 0.001 & 0.15 & 0.059 & 0.016 & 2.61 & 0.144 & 0.027 & 1.80 & 0.047 & 0.014 & 1.23 \\
\hline Primary or lower Education & 0.102 & 0.010 & 2.00 & 0.193 & 0.051 & 8.05 & 0.271 & 0.052 & 3.01 & 0.076 & 0.022 & 1.55 \\
\hline Good Health Status & 0.247 & 0.025 & 6.16 & 0.231 & 0.061 & 13.42 & 0.239 & 0.046 & 2.71 & 0.402 & 0.117 & 9.10 \\
\hline Previously unemployed & -0.125 & -0.013 & -2.46 & -0.046 & -0.012 & -1.72 & -0.257 & -0.049 & -3.80 & -0.202 & -0.059 & -5.00 \\
\hline \multicolumn{13}{|l|}{ Job characteristics } \\
\hline$\overline{\text { Overskilled }}$ & -0.351 & -0.036 & -4.31 & -0.233 & -0.061 & -7.54 & -0.325 & -0.062 & -6.36 & -0.284 & -0.082 & -11.52 \\
\hline Use of languages & -0.566 & -0.058 & -3.30 & -0.001 & 0.000 & -0.02 & 0.160 & 0.030 & 1.27 & 0.106 & 0.031 & 2.31 \\
\hline Traning at the moment & -0.017 & -0.002 & -0.41 & -0.008 & -0.002 & -0.56 & 0.007 & 0.001 & 0.10 & -0.083 & -0.024 & -3.02 \\
\hline Permanent contract & 0.283 & 0.029 & 4.90 & 0.074 & 0.020 & 2.34 & 0.183 & 0.035 & 3.03 & 0.108 & 0.031 & 2.83 \\
\hline Full-time & -0.239 & -0.024 & -3.67 & -0.156 & -0.041 & -4.23 & -0.139 & -0.026 & -1.42 & 0.089 & 0.026 & 1.57 \\
\hline Public worker & 0.271 & 0.028 & 4.16 & -0.048 & -0.013 & -2.04 & 0.060 & 0.011 & 0.60 & 0.120 & 0.035 & 3.20 \\
\hline$\mu_{1}$ & -3.558 & & -11.08 & -2.956 & & -16.09 & -1.014 & & -2.03 & -2.417 & & -7.82 \\
\hline$\mu_{2}$ & -2.950 & & -9.23 & -2.271 & & -12.38 & -0.498 & & -1.00 & -1.806 & & -5.86 \\
\hline$\mu_{3}$ & -2.352 & & -7.37 & -1.701 & & -9.28 & 0.284 & & 0.57 & -1.026 & & -3.33 \\
\hline$\mu_{4}$ & -1.358 & & -4.27 & -0.628 & & -3.43 & 1.226 & & 2.45 & -0.007 & & -0.02 \\
\hline$\mu_{5}$ & 0.297 & & 0.93 & 1.248 & & 6.81 & 2.243 & & 4.47 & 1.260 & & 4.08 \\
\hline$\rho$ & 0.534 & & 37.11 & 0.500 & & 84.03 & 0.383 & & 14.18 & 0.394 & & 34.81 \\
\hline Log-likelihood & \multicolumn{3}{|c|}{$-10,711$} & \multicolumn{3}{|c|}{$-57,298$} & \multicolumn{3}{|c|}{$-4,592$} & \multicolumn{3}{|c|}{$-18,644$} \\
\hline LR Chi-test & \multicolumn{3}{|c|}{529} & \multicolumn{3}{|c|}{1233} & \multicolumn{3}{|c|}{174} & \multicolumn{3}{|c|}{548} \\
\hline \# of observations & \multicolumn{3}{|c|}{7,526} & \multicolumn{3}{|c|}{42,783} & \multicolumn{3}{|c|}{3,010} & \multicolumn{3}{|c|}{13,700} \\
\hline
\end{tabular}

Note: Estimates also include dummy controls for employer facilities (insurance, housing, training and leisure), employer size, occupations, industry, region and year. 
Random effects ordered probit estimates

\begin{tabular}{|c|c|c|c|c|c|c|c|c|c|c|c|c|}
\hline & \multicolumn{6}{|r|}{ Italy } & & & & \multicolumn{3}{|c|}{ Greece } \\
\hline & \multicolumn{3}{|c|}{ Low-wage } & \multicolumn{3}{|c|}{ Higher-wage } & \multicolumn{3}{|c|}{ Low-wage } & \multicolumn{3}{|c|}{ Higher-wage } \\
\hline & Coeff. & APE & z-value & Coeff. & APE & z-value & Coeff. & APE & z-value & Coeff. & APE & z-value \\
\hline $\log$ (hourly wage) & 0.473 & 0.051 & 5.10 & 0.894 & 0.081 & 23.31 & 0.492 & 0.008 & 5.02 & 0.831 & 0.010 & 21.99 \\
\hline log(weekly hours) & 0.668 & 0.073 & 5.56 & 0.786 & 0.071 & 15.33 & 0.761 & 0.012 & 6.99 & 0.837 & 0.010 & 15.05 \\
\hline Age & -0.037 & -0.004 & -2.15 & -0.046 & -0.004 & -6.74 & -0.035 & -0.001 & -2.48 & -0.017 & 0.000 & -2.13 \\
\hline Age Squared/100 & 0.038 & 0.004 & 1.67 & 0.052 & 0.005 & 6.19 & 0.038 & 0.001 & 2.03 & 0.015 & 0.000 & 1.61 \\
\hline Gender (Male) & -0.077 & -0.008 & -1.18 & -0.112 & -0.010 & -4.31 & -0.036 & -0.001 & -0.68 & -0.139 & -0.002 & -6.02 \\
\hline Secondary Education & -0.161 & -0.018 & -1.23 & 0.011 & 0.001 & 0.32 & -0.121 & -0.002 & -1.61 & -0.040 & 0.000 & -1.39 \\
\hline Primary or lower Education & -0.217 & -0.024 & -1.71 & -0.039 & -0.004 & -1.05 & -0.204 & -0.003 & -2.40 & -0.154 & -0.002 & -4.22 \\
\hline Good Health Status & 0.295 & 0.032 & 5.17 & 0.266 & 0.024 & 16.40 & 0.089 & 0.001 & 0.98 & 0.100 & 0.001 & 2.62 \\
\hline Previously unemployed & -0.059 & -0.006 & -0.97 & -0.114 & -0.010 & -4.00 & -0.096 & -0.002 & -1.85 & -0.139 & -0.002 & -5.25 \\
\hline \multicolumn{13}{|l|}{ Job characteristics } \\
\hline$\overline{\text { Overskilled }}$ & -0.059 & -0.006 & -1.14 & -0.076 & -0.007 & -4.89 & -0.287 & -0.005 & -5.89 & -0.180 & -0.002 & -9.23 \\
\hline Use of languages & 0.112 & 0.012 & 0.86 & 0.049 & 0.004 & 1.67 & 0.181 & 0.003 & 2.09 & 0.091 & 0.001 & 3.11 \\
\hline Traning at the moment & 0.117 & 0.013 & 1.27 & 0.088 & 0.008 & 4.15 & 0.191 & 0.003 & 2.28 & 0.210 & 0.003 & 6.35 \\
\hline Permanent contract & 0.187 & 0.020 & 3.39 & 0.201 & 0.018 & 7.69 & 0.469 & 0.007 & 9.44 & 0.413 & 0.005 & 14.82 \\
\hline Full-time & 0.024 & 0.003 & 0.22 & -0.057 & -0.005 & -1.56 & -0.016 & 0.000 & -0.14 & 0.156 & 0.002 & 3.08 \\
\hline Public worker & 0.475 & 0.052 & 4.72 & 0.156 & 0.014 & 6.74 & 0.410 & 0.007 & 4.75 & 0.372 & 0.005 & 14.20 \\
\hline$\mu_{1}$ & 0.237 & & 0.45 & 1.087 & & 4.56 & 1.446 & & 2.53 & 1.745 & & 6.93 \\
\hline$\mu_{2}$ & 1.258 & & 2.40 & 1.904 & & 7.98 & 2.451 & & 4.28 & 2.587 & & 10.28 \\
\hline$\mu_{3}$ & 2.288 & & 4.36 & 2.883 & & 12.07 & 3.600 & & 6.27 & 3.710 & & 14.70 \\
\hline$\mu_{4}$ & 3.200 & & 6.08 & 4.002 & & 16.74 & 4.636 & & 8.05 & 4.805 & & 18.97 \\
\hline$\mu_{5}$ & 4.358 & & 8.23 & 5.279 & & 22.03 & 5.590 & & 9.65 & 5.938 & & 23.36 \\
\hline$\rho$ & 0.484 & & 21.56 & 0.411 & & 62.17 & 0.264 & & 10.49 & 0.203 & & 22.46 \\
\hline Log-likelihood & \multicolumn{3}{|c|}{$-5,896$} & \multicolumn{3}{|c|}{$-51,525$} & \multicolumn{3}{|c|}{$-4,548$} & \multicolumn{3}{|c|}{$-23,947$} \\
\hline LR Chi-test & \multicolumn{3}{|c|}{592} & \multicolumn{3}{|c|}{2717} & \multicolumn{3}{|c|}{538} & \multicolumn{3}{|c|}{2784} \\
\hline \# of observations & \multicolumn{3}{|c|}{3,813} & \multicolumn{3}{|c|}{36,238} & \multicolumn{3}{|c|}{3,134} & \multicolumn{3}{|c|}{17,210} \\
\hline
\end{tabular}

Note: Estimates also include dummy controls for employer facilities (insurance, housing, training and leisure), employer size, occupations, industry, region and year. 
Random effects ordered probit estimates

\begin{tabular}{|c|c|c|c|c|c|c|c|c|c|c|c|c|}
\hline & \multicolumn{6}{|r|}{ Spain } & & & & \multicolumn{3}{|c|}{ Portugal } \\
\hline & \multicolumn{3}{|c|}{ Low-wage } & \multicolumn{3}{|c|}{ Higher-wage } & \multicolumn{3}{|c|}{ Low-wage } & \multicolumn{3}{|c|}{ Higher-wage } \\
\hline & Coeff. & APE & z-value & Coeff. & APE & z-value & Coeff. & APE & z-value & Coeff. & APE & z-value \\
\hline log(hourly wage) & 0.296 & 0.100 & 4.72 & 0.422 & 0.099 & 14.20 & 0.077 & 0.014 & 1.23 & 0.684 & 0.084 & 19.93 \\
\hline log(weekly hours) & 0.119 & 0.040 & 1.56 & 0.311 & 0.073 & 5.85 & 0.571 & 0.101 & 4.89 & 0.670 & 0.082 & 10.15 \\
\hline Age & -0.029 & -0.010 & -3.17 & -0.062 & -0.015 & -10.91 & -0.026 & -0.005 & -1.98 & -0.015 & -0.002 & -2.26 \\
\hline Age Squared/100 & 0.030 & 0.010 & 2.57 & 0.078 & 0.018 & 11.12 & 0.031 & 0.005 & 1.83 & 0.012 & 0.001 & 1.49 \\
\hline Gender (Male) & -0.128 & -0.043 & -3.44 & -0.126 & -0.030 & -6.10 & -0.039 & -0.007 & -0.60 & -0.009 & -0.001 & -0.31 \\
\hline Secondary Education & 0.078 & 0.026 & 1.35 & 0.011 & 0.003 & 0.44 & -0.694 & -0.122 & -2.49 & -0.007 & -0.001 & -0.16 \\
\hline Primary or lower Education & 0.255 & 0.086 & 4.52 & 0.105 & 0.025 & 4.03 & -0.736 & -0.130 & -2.73 & -0.010 & -0.001 & -0.21 \\
\hline Good Health Status & 0.207 & 0.070 & 5.07 & 0.253 & 0.059 & 12.76 & 0.008 & 0.001 & 0.16 & 0.096 & 0.012 & 5.05 \\
\hline Previously unemployed & -0.206 & -0.070 & -6.11 & -0.089 & -0.021 & -4.46 & -0.231 & -0.041 & -3.49 & -0.164 & -0.020 & -4.81 \\
\hline \multicolumn{13}{|l|}{$\underline{\text { Job characteristics }}$} \\
\hline Overskilled & -0.190 & -0.064 & -5.88 & -0.140 & -0.033 & -9.32 & -0.172 & -0.030 & -3.56 & -0.109 & -0.013 & -6.28 \\
\hline Use of languages & -0.100 & -0.034 & -1.18 & 0.021 & 0.005 & 0.72 & 0.487 & 0.086 & 3.15 & -0.024 & -0.003 & -0.70 \\
\hline Traning at the moment & 0.024 & 0.008 & 0.54 & 0.010 & 0.002 & 0.56 & -0.024 & -0.004 & -0.27 & 0.049 & 0.006 & 1.66 \\
\hline Permanent contract & 0.135 & 0.046 & 3.60 & 0.110 & 0.026 & 5.60 & 0.313 & 0.055 & 5.82 & 0.245 & 0.030 & 10.67 \\
\hline Full-time & -0.017 & -0.006 & -0.24 & -0.008 & -0.002 & -0.17 & 0.174 & 0.031 & 1.41 & 0.129 & 0.016 & 2.12 \\
\hline Public worker & 0.227 & 0.077 & 3.29 & 0.130 & 0.031 & 5.74 & -0.006 & -0.001 & -0.05 & 0.223 & 0.027 & 8.14 \\
\hline$\mu_{1}$ & -1.505 & & -5.04 & -1.351 & & -6.46 & -1.361 & & -2.61 & -0.121 & & -0.47 \\
\hline$\mu_{2}$ & -0.792 & & -2.66 & -0.683 & & -3.27 & -0.298 & & -0.57 & 0.683 & & 2.68 \\
\hline$\mu_{3}$ & -0.086 & & -0.29 & 0.083 & & 0.40 & 0.902 & & 1.74 & 1.789 & & 7.02 \\
\hline$\mu_{4}$ & 0.604 & & 2.03 & 0.925 & & 4.43 & 2.853 & & 5.48 & 3.916 & & 15.32 \\
\hline$\mu_{5}$ & 1.665 & & 5.57 & 2.249 & & 10.75 & 3.812 & & 7.29 & 5.414 & & 21.11 \\
\hline$\rho$ & 0.177 & & 10.15 & 0.242 & & 32.52 & 0.467 & & 22.96 & 0.435 & & 58.58 \\
\hline Log-likelihood & \multicolumn{3}{|c|}{$-9,674$} & \multicolumn{3}{|c|}{$-41,872$} & \multicolumn{3}{|c|}{$-5,435$} & \multicolumn{3}{|c|}{$-33,184$} \\
\hline LR Chi-test & \multicolumn{3}{|c|}{496} & \multicolumn{3}{|c|}{1872} & \multicolumn{3}{|c|}{320} & \multicolumn{3}{|c|}{1962} \\
\hline \# of observations & \multicolumn{3}{|c|}{5.919} & \multicolumn{3}{|c|}{29.000} & \multicolumn{3}{|c|}{4.232} & \multicolumn{3}{|c|}{30,318} \\
\hline
\end{tabular}

Note: Estimates also include dummy controls for employer facilities (insurance, housing, training and leisure), employer size, occupations, industry, region and year. 
Random effects ordered probit estimates

\begin{tabular}{|c|c|c|c|c|c|c|c|c|c|c|c|c|}
\hline & \multicolumn{6}{|r|}{ Austria } & \multicolumn{6}{|c|}{ Finland } \\
\hline & \multicolumn{3}{|c|}{ Low-wage } & \multicolumn{3}{|c|}{ Higher-wage } & \multicolumn{3}{|c|}{ Low-wage } & \multicolumn{3}{|c|}{ Higher-wage } \\
\hline & Coeff. & APE & z-value & Coeff. & APE & z-value & Coeff. & APE & z-value & Coeff. & APE & z-value \\
\hline $\log ($ hourly wage) & -0.124 & -0.035 & -2.02 & 0.496 & 0.086 & 8.87 & -0.060 & -0.005 & -0.60 & 0.553 & 0.156 & 9.74 \\
\hline $\log$ (weekly hours) & -0.165 & -0.046 & -1.10 & 0.147 & 0.026 & 1.74 & 0.033 & 0.003 & 0.27 & 0.457 & 0.129 & 5.43 \\
\hline Age & -0.027 & -0.007 & -1.11 & -0.039 & -0.007 & -4.04 & 0.005 & 0.000 & 0.23 & -0.023 & -0.007 & -2.35 \\
\hline Age Squared/100 & 0.028 & 0.008 & 0.85 & 0.050 & 0.009 & 3.98 & -0.002 & 0.000 & -0.05 & 0.037 & 0.010 & 2.97 \\
\hline Gender (Male) & 0.021 & 0.006 & 0.22 & -0.173 & -0.030 & -4.28 & 0.130 & 0.011 & 1.52 & -0.095 & -0.027 & -2.83 \\
\hline Secondary Education & 0.563 & 0.157 & 3.14 & 0.091 & 0.016 & 1.61 & -0.002 & 0.000 & -0.02 & 0.089 & 0.025 & 2.63 \\
\hline Primary or lower Education & 0.454 & 0.127 & 2.40 & 0.083 & 0.014 & 1.22 & -0.002 & 0.000 & -0.02 & 0.266 & 0.075 & 5.92 \\
\hline Good Health Status & 0.473 & 0.132 & 4.96 & 0.417 & 0.073 & 12.68 & 0.324 & 0.027 & 3.69 & 0.283 & 0.080 & 10.18 \\
\hline Previously unemployed & -0.158 & -0.044 & -1.69 & -0.119 & -0.021 & -2.77 & -0.210 & -0.018 & -2.46 & 0.036 & 0.010 & 1.02 \\
\hline \multicolumn{13}{|l|}{ Job characteristics } \\
\hline$\overline{\text { Overskilled }}$ & -0.455 & -0.127 & -6.51 & -0.174 & -0.030 & -7.91 & -0.150 & -0.013 & -1.94 & -0.212 & -0.060 & -8.88 \\
\hline Use of languages & 0.046 & 0.013 & 0.43 & -0.020 & -0.004 & -0.63 & -0.036 & -0.003 & -0.35 & 0.113 & 0.032 & 3.84 \\
\hline Traning at the moment & -0.067 & -0.019 & -0.81 & 0.014 & 0.002 & 0.56 & -0.073 & -0.006 & -0.94 & 0.047 & 0.013 & 2.02 \\
\hline Permanent contract & 0.192 & 0.054 & 2.24 & 0.216 & 0.038 & 5.27 & -0.151 & -0.013 & -1.80 & -0.122 & -0.034 & -3.38 \\
\hline Full-time & 0.148 & 0.041 & 1.12 & -0.091 & -0.016 & -1.40 & 0.130 & 0.011 & 1.05 & -0.168 & -0.047 & -2.35 \\
\hline Public worker & 0.103 & 0.029 & 0.89 & 0.143 & 0.025 & 3.97 & 0.085 & 0.007 & 0.92 & 0.043 & 0.012 & 1.41 \\
\hline$\mu_{1}$ & -3.006 & & -4.66 & -1.908 & & -5.26 & -2.450 & & -4.37 & -1.169 & & -3.00 \\
\hline$\mu_{2}$ & -2.296 & & -3.58 & -1.310 & & -3.63 & -1.809 & & -3.26 & -0.340 & & -0.88 \\
\hline$\mu_{3}$ & -1.773 & & -2.77 & -0.718 & & -1.99 & -0.960 & & -1.74 & 0.570 & & 1.47 \\
\hline$\mu_{4}$ & -0.702 & & -1.10 & 0.476 & & 1.32 & 0.081 & & 0.15 & 1.822 & & 4.70 \\
\hline$\mu_{5}$ & 0.668 & & 1.05 & 2.044 & & 5.65 & 1.545 & & 2.78 & 3.637 & & 9.36 \\
\hline$\rho$ & 0.427 & & 12.35 & 0.420 & & 42.17 & 0.346 & & 7.27 & 0.413 & & 40.88 \\
\hline Log-likelihood & \multicolumn{3}{|c|}{$-2,551$} & \multicolumn{3}{|c|}{$-19,963$} & \multicolumn{3}{|c|}{$-2,079$} & \multicolumn{3}{|c|}{$-19,649$} \\
\hline LR Chi-test & \multicolumn{3}{|c|}{211} & \multicolumn{3}{|c|}{709} & \multicolumn{3}{|c|}{105} & \multicolumn{3}{|c|}{700} \\
\hline \# of observations & \multicolumn{3}{|c|}{1,922} & \multicolumn{3}{|c|}{17,356} & \multicolumn{3}{|c|}{1,492} & \multicolumn{3}{|c|}{16,246} \\
\hline
\end{tabular}

Note: Estimates also include dummy controls for employer facilities (insurance, housing, training and leisure), employer size, occupations, industry, region and year. 